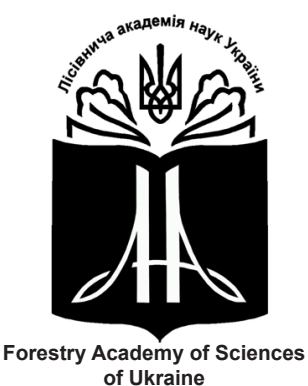

УДК $630 * 611: 630 * 624: 630 * 641$

Наукові праці Лісівничої академії наук України

Proceedings of the Forestry Academy of Sciences of Ukraine

http://fasu.nltu.edu.ua

https://doi.org/ 411711

Article received 2017.09.02

Article accepted 2017.11.15
ISSN 1991-606X print

ISSN 2616-5015 online

(a) $\triangle$ Correspondence author

Yu. Kahaniak

kaganiak@yahoo.ca

\title{
Вікова структура різновікових букових деревостанів Українських Карпат та особливості нагромадження ними запасу
}

\author{
Ю.Й. Каганяк' ${ }^{1}$ М.П. Горошко²
}

Запропоновано результати досліджень вікової структури та динаміки нагромадженого запасу різновіковими буковими деревостанами в Українських Карпатах. Проаналізовано різновікові деревостани двох категорій: у яких здійснено головне рубання, і в яких головне рубання не проектується. Розглянуто об'єкти із різною кількістю поколінь лісу. Кількість поколінь лісу змінюється від двох до п'яти.

Прогноз нагромадженого запасу диферениійовано за поколіннями лісу та подано в інтегрованому вигляді в изілому для деревостану. Період прогнозу прийнято в межах від 0 до 320 років. Середній вік найстаршого (першого) покоління лісу поточного цииклу збігається із числовою величиною періоду прогнозу запасу. Середній вік інших поколінь лісу зміщений відносно періоду прогнозу запасу. Цей показник вирахувано за наведеним у науковій праці алгоритмом. Запас покоління лісу обчислено за моделлю параболи другого порядку, аргументом котрої є вік.

Для рядів прогнозу теоретичних значень запасу різновікових букових деревостанів із різною кількістю поколінь лісу та режимом лісовикористання обчислено основні статистики. Йдеться про середній запас деревостану, вирахуваний загалом для періоду прогнозу, а також стандартне відхилення запасу, коефіцієнт мінливості запасу та максимальні (мінімальні) відхилення запасу від середньої його величини.

Враховуючи амплітуду запасу та інші статистики, за оптимальну модель прийнято різновіковий буковий деревостан, який складається із 4-5 поколінь лісу.

Ключові слова: теорія, модель, динаміка, вибіркове господарство, вікове покоління лісу, форма господарства, амплітуда

Вступ. Лісовий сектор економіки України перебуває в умовах, коли в практику ведення лісового господарства впроваджують нові підходи та модифікують чинні. Такі нововведення є об'єктивними й актуальними, оскільки незворотними є структурні зміни економіки цілої держави та пов'язаної із нею політики.

Фактом вже стало широке запровадження основних принципів концепції наближеного до природи лісівництва (Krynytskyy, Chernyavsky, Derbal et al., 2014). Основні іiі еколого-лісівничі аспекти де- тально опрацьовано, науково обгрунтовано та широко популяризовано (Holubets, 2016, Krynytskyy, Chernyavsky, Derbal et al., 2014).

Зрозуміло, що практичне втілення цієї концепції не може відбутися миттєво, а безперечно займе більш-менш тривалий період. За цей час доцільним $\epsilon$ особливо тісний зв'язок між наукою та практикою. Це дасть змогу вчасно реагувати на ймовірні проблеми, які зазвичай виникають під час апробації нових теоретичних положень у виробничу діяльність.

Каганяк Юліан Йосипович - член-кореспондент Лісівничої академії наук України, доктор сільськогосподарських наук, професор кафедри лісової таксації та лісовпорядкування. Національний лісотехнічний університет України, вул. генерала Чупринки, 103, м. Львів, 79057, Україна. Тел.: +38-067-587-42-66. E-mail: kaganiak@yahoo.ca

Горошко Мирон Петрович - член-кореспондент Лісівничої академії наук України, кандидат сільськогосподарських наук, професор, завідувач кафедри лісової таксації та лісовпорядкування. Національний лісотехнічний університет України, вул. генерала Чупринки, 103 , м. Львів, 79057, Україна. Тел.: +38-097-500-90-09. E-mail: mag_lanu@ukr.net 
Безпосереднім об'єктом ведення господарства лісового підприємства на принципах наближеного до природи лісівництва $є$ різновіковий деревостан. Від вичерпності і достовірності інформації про такий об'єкт залежатиме правильність організації вибіркового господарства. Саме таку форму господарства вважають найбажанішою, і що найкраще відображає зміст концепції (Hirs, Novak \& Kashpor, 2013, Krynytskyy, Chernyavsky, Derbal et al., 2014). Отже, перед науковцями виникла необхідність реалізації низки лісотаксаційних досліджень у різновікових деревостанах. Насамперед вивченню підлягають структура та продуктивність таких лісових екосистем (Anuchin, 1969, Verkhunov, 1979, Voropanov, 1950, Gusev, 1978, Kuznetsova \& Stoliarov, 1981, Stoliarov \& Poluboyarinov, 1989, Kahaniak, 2006, 2012, Kahaniak \& Rehuhs, 2014). Тоді таксаційна наука отримує необхідну базову інформацію про запас, його особливості нагромадження у динаміці, тобто про найважливіший індикатор, за яким оцінюють сталість розвитку лісового господарства на різних територіальних рівнях його агрегування (Kahaniak \& Horoshko, 2016).

Зважаючи, що різновікові деревостани надзвичайно різноманітні як за продуктивністю, так і за структурою, закономірним кроком $€$ їхнє детальне вивчення.

Наші попередні дослідження структури вікових поколінь різновікового букового деревостану в Карпатах дають змогу зробити деякі узагальнення (Kahaniak, 2011). Так, кількість вікових поколінь різновікового букового деревостану змінюється від 2-х до 5-ти. Нормальність розподілу запасу між віковими поколіннями порушена різними чинниками. Основним чинником потрібно вважати відсутність нормального динамічного розподілу вікових поколінь. Тут ідеться про проміжок часу між середнім віком суміжних вікових поколінь, який, зазвичай, є різним.

Отже, доводиться констатувати порушену фактичну вікову структуру різновікових букових деревостанів у лісовому фонді Карпатського регіону.

Водночас саме вікова структура та пов'язаний iз нею перерозподіл запасу між віковими поколіннями лісу є визначальним чинником, що безпосередньо впливає на ефективність лісовикористання деревини, стабільність продукування стиглого лісу на зазначеній площі (Svalov, 1979). Це свідчить про особливу значущість теоретичного обгрунтування заходів, пов'язаних із програмою сталого використання стиглої деревини в обмежених за площею (малих) господарствах.

Предмет досліджень - вікова структура різновікових деревостанів i динаміка нагромадження ними запасу стовбурової деревини на прикладі букових лісостанів у Карпатах.

Мета дослідження полягає у встановленні зв'язку, тенденції чи закономірності між кількістю вікових поколінь лісу букового деревостану та величиною нагромадженого деревного запасу. Очікуваним результатом є вибір оптимального варіанта вікової структури об’єкта для застосування як еталону на лісовому підприємстві.
Методика досліджень. Дослідженню підлягали різновікові деревостани бука лісового в Карпатах із 2-5-вікових поколінь лісу. У моделі аксіоматично припускається за найбажаніше рівномірне відтворення дерев бука лісового, що дає змогу аналізувати деревостан, в якому суміжні вікові покоління рівновіддалені одні від одних.

Об'єкт поділено на дві групи за відношенням до головного використання деревного запасу: 1) різновіковий буковий деревостан без рубання головного користування та 2) різновіковий буковий деревостан з рубанням головного користування.

Об'єкти, що належать до першої групи, характеризуються нижчою інтенсивністю відтворення, порівняно із деревостанами другої групи. Інтенсивність відтворення запасу різниться вдвічі, оскільки період росту і розвитку покоління лісу першої групи -320 років, а другої - 160 .

Запас вікового покоління лісу (M) описано в динаміці (залежно від середнього віку А) за формулою параболи другого порядку $\mathrm{M}=\mathrm{b} \cdot \mathrm{A}+\mathrm{c} \cdot \mathrm{A}^{2}$. Для отримання запасу покоління лісу потрібно обчислити середній вік.

Ми задали період прогнозу запасу $\left(\mathrm{U}_{1}\right)$, який прийнято рівним часу росту і розвитку вікового покоління лісу деревостану першої групи, тобто 320 років. Прогноз нагромадження запасу кратний 20 рокам, що відповідає класу віку різновікового букового деревостану.

Період прогнозу запасу приймається рівним середньому віку найстаршого (першого) вікового покоління лісу для поточного (нульового) циклу й описується виразом (1):

$$
U_{1}=A_{1}^{0 ц},
$$

Середній вік інших вікових поколінь, як поточного, так і попереднього (наступного) циклів, визначається за наведеним нижче алгоритмом. Визначення середнього віку покоління лісу специфічне в обох групах об'єкта досліджень.

Алгоритм визначення середнього віку поколінь лісу для різновікового букового деревостану без рубань головного користування (перша група) зводиться до попереднього обчислення $A_{k}^{0 ц}$ поточного циклу за такою базовою формулою (2):

$$
A_{k}^{0 ц}=A_{1}^{0 ц}-(k-1) \varepsilon \cdot \mathrm{U},
$$

де $\mathrm{k}$ - індекс вікового покоління, починаючи iз другого $(2, \ldots, \mathrm{i})$; $\mathrm{U}$ - вік природної стиглості (приймають тотожним із віком головного рубання, тобто 160), років; $\varepsilon$ - параметр, який враховує кількість поколінь лісу в різновіковому деревостані (вираховують $1 / \mathrm{k}$ : для деревостану із 5-ти поколінь лісу 0,2 , із 4-х поколінь - 0,25 , із $3-x-0,33$, iз $2-\mathrm{x}-0,5)$.

Якщо $A_{k}^{0 ц}<0$, тоді остаточно результати обчислення середнього віку покоління лісу за формулою (2) приймають рівними 0. За інших умов фіксують середній вік покоління лісу для поточного циклу, отриманий за формулою (2).

Середній вік покоління лісу попереднього циклу вираховують за формулою 


$$
A_{k}^{\text {пц }}=\text { формула } 2+2 \cdot U,
$$

Якщо $A_{k}^{0 ц} \leq 0$, тоді середній вік покоління лісу для попереднього циклу обчислюють за формулою (3). За інших умов середній вік покоління лісу для попереднього циклу приймають рівним 0 .

Алгоритм визначення середнього віку поколінь лісу різновікового букового деревостану з рубанням головного користування (друга група) теж зводиться

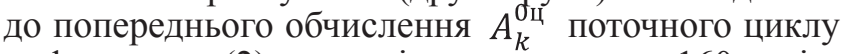
за формулою (2) для періоду прогнозу до 160 років.

Для поточного циклу, якщо $A_{k}^{0 щ}<0$, тоді остаточно середній вік покоління лісу, обчислений за формулою (2), приймають рівним 0. За інших умов фіксують середній вік поточного циклу, отриманий за формулою (2).

Для попереднього циклу, якщо $A_{k}^{0 ц}>0$, тоді остаточно середній вік покоління лісу, обчислений за формулою (2), приймають рівним 0. За інших умов фіксують середній вік покоління лісу для попереднього циклу, отриманий за формулою

$$
A^{\text {пц }}=\text { формула } 2+U,
$$

Алгоритм визначення середнього віку поколінь лісу різновікового букового деревостану з рубанням головного користування (друга група) зводиться до попереднього обчислення $A_{k}^{0 ц}$ поточного циклу за формулою (2) для періоду прогнозу понад 160 років.

Якщо $A_{k}^{\text {0Щ }} \leq 160$, тоді середній вік покоління лісу поточного циклу обчислюють за формулою (2). За інших умов середній вік покоління лісу для поточного циклу приймають рівним 0.

Якщо $A_{k}^{0 \Perp}>160$, тоді середній вік покоління лісу для наступного циклу обчислюють за формулою (5).
За інших умов середній вік покоління лісу для наступного циклу приймають рівним 0 :

$$
A_{k}^{\text {нц }}=\text { формула } 2-U .
$$

Апріорі нормальним приймають рівномірне відтворення запасу, тобто часовий інтервал між середнім віком поколінь лісу однаковий.

Результати досліджень. За результатами обчислення прогнозу нагромадження запасу різновіковими деревостанами Іа бонітету із різною кількістю вікових поколінь лісу та різним режимом лісовикористання за наведеним вище алгоритмом отримано динамічні ряди. Схематичне зображення динаміки запасу різновікових букових деревостанів диференційовано за поколіннями лісу показано на рис. 1.

Динаміку запасу для різновікових букових деревостанів з головним рубанням здійснено для поточного, попереднього та наступного циклів, які потрапляють у 320-річний період прогнозу. Динаміку запасу для різновікових букових деревостанів без головного рубання здійснено для поточного та попереднього циклів.

Табульовані значення динаміки запасу згаданих різновікових букових деревостанів із головним рубанням подано в табл. 1, в якій наведено запас, підсумований в цілому для деревостану.

Табульовані значення динаміки запасу згаданих різновікових букових деревостанів без головного рубання подано в табл. 2.

Отримані в табл. 1, 2 динамічні ряди (прогноз запасу різновікових деревостанів із різною кількістю поколінь лісу та режимом лісовикористання) опрацьовано статистично, а основні характеристики подано в табл. 3.

Таблиия 1

\begin{tabular}{|c|c|c|c|c|c|c|c|c|c|}
\hline \multirow{2}{*}{$\begin{array}{c}\text { Період } \\
\text { прогнозу, } \\
\text { років }\end{array}$} & \multicolumn{4}{|c|}{$\begin{array}{c}\text { Запас деревостану залежно } \\
\text { від кількості поколінь лісу, м³/га }\end{array}$} & \multirow{2}{*}{$\begin{array}{c}\text { Період } \\
\text { прогнозу, } \\
\text { років }\end{array}$} & \multicolumn{4}{|c|}{$\begin{array}{c}\text { Запас деревостану залежно } \\
\text { від кількості поколінь лісу, м³/га }\end{array}$} \\
\hline & 5 & 4 & 3 & 2 & & 5 & 4 & 3 & 2 \\
\hline 0 & 750 & 771 & 797 & 864 & 180 & 686 & 663 & 618 & 540 \\
\hline 20 & 686 & 663 & 618 & 540 & 192 & 750 & 732 & 692 & 627 \\
\hline 32 & 750 & 732 & 692 & 627 & 200 & 610 & 771 & 735 & 679 \\
\hline 40 & 610 & 771 & 735 & 679 & 213 & 691 & 618 & 795 & 753 \\
\hline 53 & 691 & 618 & 795 & 753 & 220 & 730 & 663 & 523 & 787 \\
\hline 60 & 730 & 663 & 523 & 787 & 224 & 750 & 687 & 553 & 805 \\
\hline 64 & 750 & 687 & 553 & 805 & 240 & 662 & 771 & 661 & 864 \\
\hline 80 & 662 & 771 & 661 & 864 & 256 & 750 & 638 & 749 & 509 \\
\hline 96 & 750 & 638 & 749 & 509 & 260 & 582 & 663 & 768 & 540 \\
\hline 100 & 582 & 663 & 768 & 540 & 267 & 630 & 705 & 473 & 592 \\
\hline 107 & 630 & 705 & 473 & 592 & 280 & 708 & 771 & 572 & 679 \\
\hline 120 & 708 & 771 & 572 & 679 & 288 & 750 & 584 & 627 & 726 \\
\hline 128 & 750 & 584 & 627 & 726 & 300 & 636 & 663 & 700 & 787 \\
\hline 140 & 636 & 663 & 700 & 787 & 320 & 750 & 771 & 797 & 864 \\
\hline 160 & 750 & 771 & 797 & 864 & - & - & - & - & - \\
\hline
\end{tabular}

Прогноз нагромадження запасу різновіковими буковими деревостанами Ia бонітету з головним рубанням (у 160 років) залежно від кількості поколінь лісу

Примітка. Період прогнозу, не кратний 20 рокам, введено до таблиці для фіксації місця у цьому статистичному ряду поколінь лісу в деревостанах, які досягли віку 160 років. Враховано для деревостанів із п’яти і трьох поколінь лісу. Досягнення віку 160 років поколіннями лісу (за винятком найстаршого) потрапляє між 20-річні градації класів періоду прогнозу. 


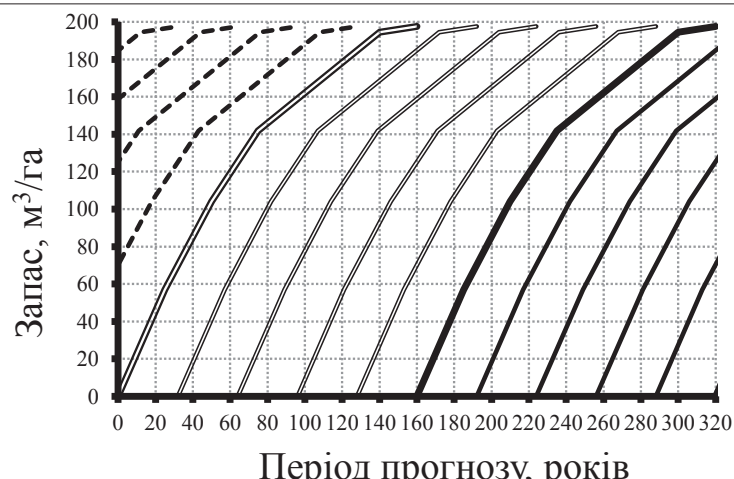

Період прогнозу, років

$\left.\mathrm{a}_{1}\right)$

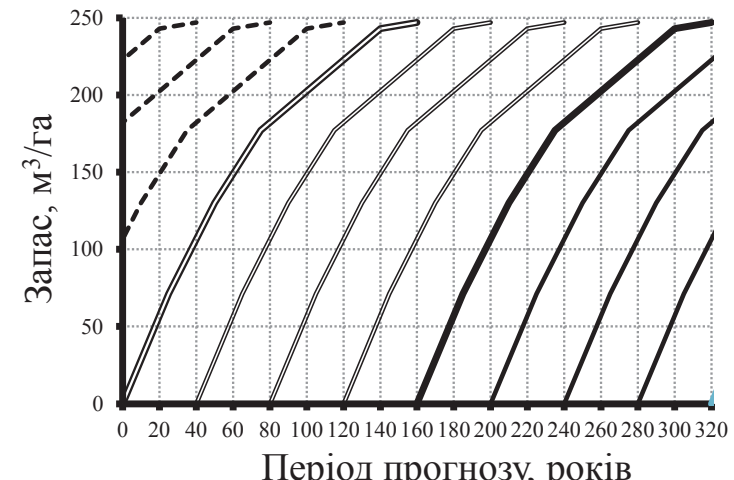

$\left.\mathrm{b}_{1}\right)$

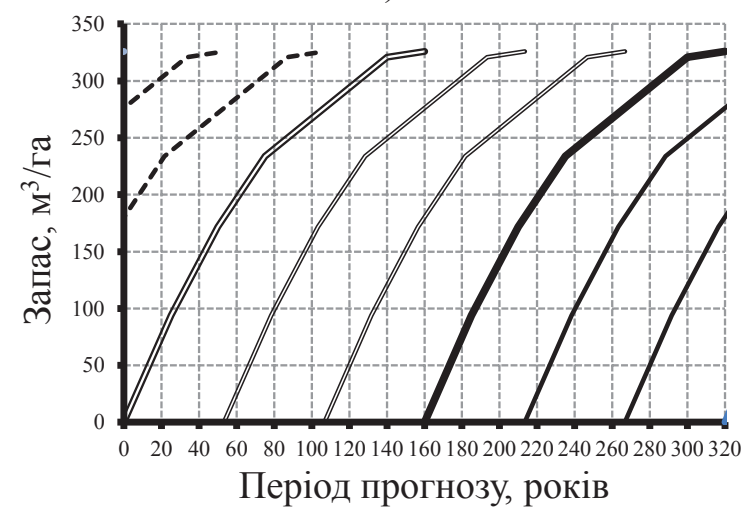

$\left.\mathrm{c}_{1}\right)$

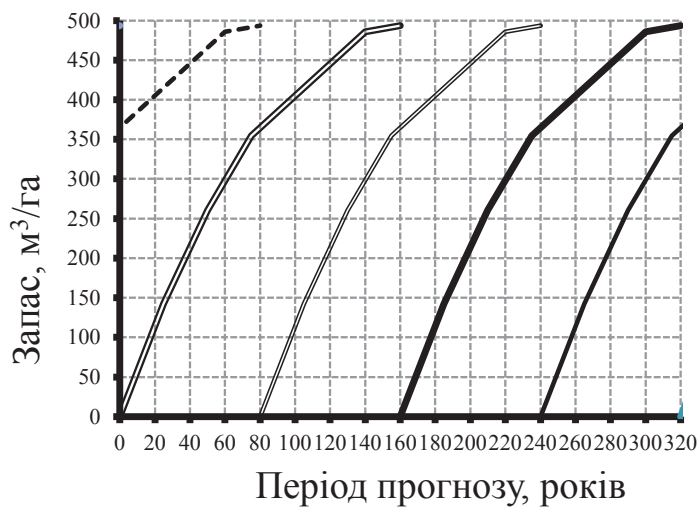

$\left.\mathrm{d}_{1}\right)$

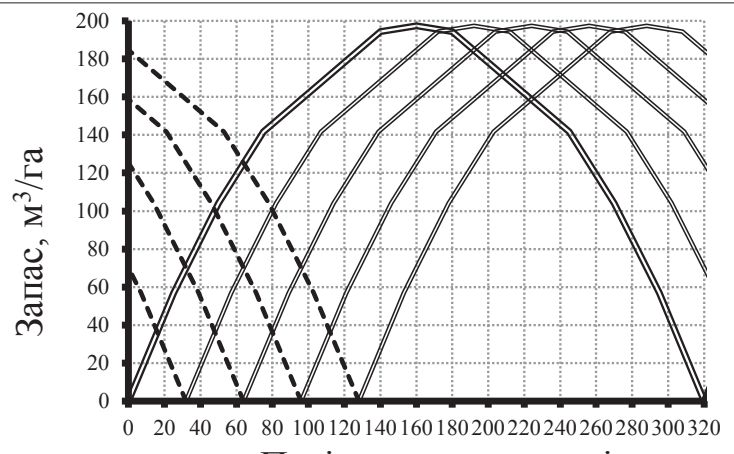

Період прогнозу, років

$\left.\mathrm{a}_{2}\right)$

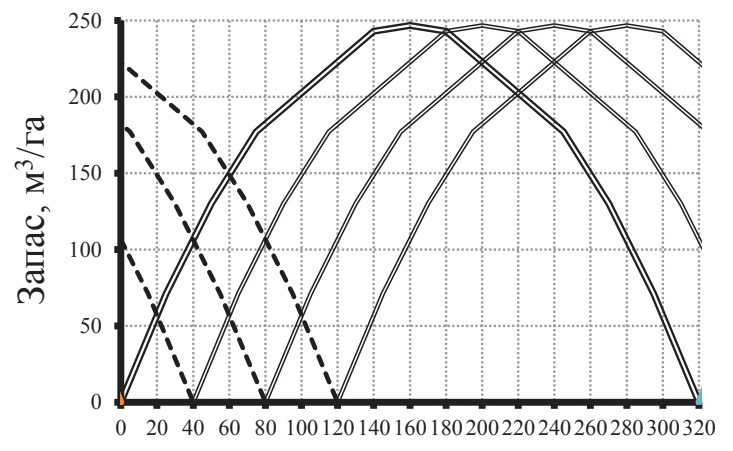

Період прогнозу, років

$\left.\mathrm{b}_{2}\right)$

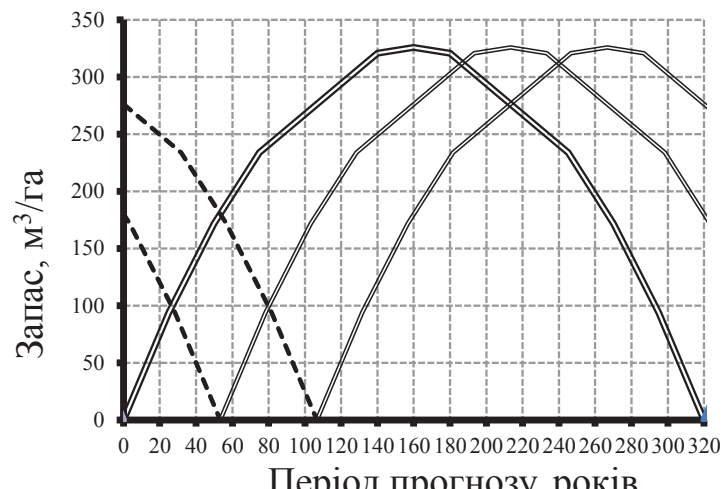

Період прогнозу, років

$\left.\mathrm{c}_{2}\right)$

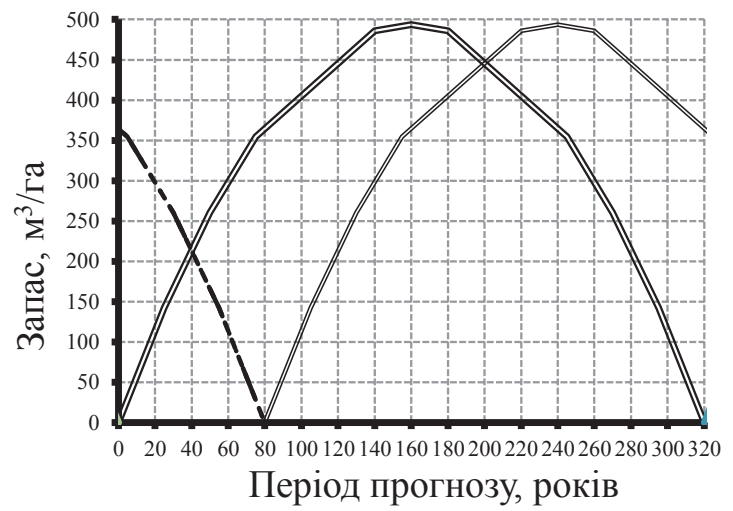

$\left.\mathrm{d}_{2}\right)$

Рис. 1. Особливості нагромадження запасу різновіковими буковими деревостанами I ${ }^{\mathrm{a}}$ бонітету в Українських Карпатах за віковими поколіннями:
$\mathrm{a}_{1}$ ) п’ять поколінь із головним рубанням;
$\mathrm{a}_{2}$ ) п'ять поколінь без головного рубання;
$\mathrm{b}_{1}$ ) чотири покоління з головним рубанням;
$\mathrm{b}_{2}$ ) чотири покоління без головного рубання;
$\mathrm{c}_{1}$ ) три покоління 3 головним рубанням;
$\mathrm{c}_{2}$ ) три покоління без головного рубання;
$\mathrm{d}_{1}$ ) два покоління з головним рубанням;
$\mathrm{d}_{2}$ ) два покоління без головного рубання 
Статистичний аналіз підтверджено графічною презентацією рядів прогнозу запасу для зазначених різновікових букових деревостанів, яку подано на рис. 2. На рисунку подвійна лінія відображає прогноз запасу для різновікового деревостану із 4 поколінь лісу, пунктирна із крапкою - із 5 поколінь, пунктирна - із 3, точками - із 2 поколінь лісу.

Для економіки лісогосподарського підприємства має більше практичне значення прогноз запасу для різновікових деревостанів із головним рубанням. Тому логічною $є$ оптимізація кількості поколінь лісу. Для вирішення такого завдання можна використати інформацію статистичного аналізу, подану в табл. 3. Важливо врахувати не лише удвічі інтенсивніше відтворення запасу в деревостанах з голов- ним рубанням, але й амплітуду коливання запасу впродовж періоду прогнозу.

Ми отримали такі результати для різновікових деревостанів із головним рубанням, що відображено на рис. 3.

Амплітуда запасу зростає зі збільшенням кількості поколінь лісу. У деревостанах без головного рубання зменшення кількості поколінь лісу менш відчутно збільшує коливання запасу (на $5 \%$ ). У деревостанах із головним рубанням із 4-5-ти поколінь лісу амплітуда запасу вдвічі менша, ніж у деревостанах із 3-2-х поколінь.

3 теорії дослідження вікової структури різновікових деревостанів відомо, що оптимальним варіантом є деревостан із мінімальною амплітудою коливання запасу (Svalov, 1979).

Таблиия 2

Прогноз нагромадження запасу різновіковими буковими деревостанами $\mathrm{I}^{\mathrm{a}}$ бонітету без головного рубання залежно від кількості поколінь лісу

\begin{tabular}{|c|c|c|c|c|c|c|c|c|c|}
\hline \multirow{2}{*}{$\begin{array}{c}\text { Період } \\
\text { прогнозу, } \\
\text { років }\end{array}$} & \multicolumn{4}{|c|}{$\begin{array}{c}\text { Запас деревостану залежно } \\
\text { від кількості поколінь лісу, м³/га }\end{array}$} & \multirow{2}{*}{$\begin{array}{c}\text { Період } \\
\text { прогнозу, } \\
\text { років }\end{array}$} & \multicolumn{4}{|c|}{$\begin{array}{c}\text { Запас деревостану залежно } \\
\text { від кількості поколінь лісу, м³/га }\end{array}$} \\
\hline & 5 & 4 & 3 & 2 & & 5 & 4 & 3 & 2 \\
\hline 0 & 553 & 525 & 471 & 370 & 180 & 834 & 849 & 863 & 910 \\
\hline 20 & 488 & 478 & 455 & 417 & 200 & 886 & 895 & 898 & 926 \\
\hline 40 & 432 & 401 & 410 & 432 & 220 & 908 & 910 & 903 & 910 \\
\hline 60 & 404 & 417 & 388 & 417 & 240 & 899 & 895 & 878 & 864 \\
\hline 80 & 425 & 401 & 444 & 370 & 260 & 858 & 849 & 822 & 787 \\
\hline 100 & 454 & 478 & 469 & 540 & 280 & 787 & 771 & 735 & 679 \\
\hline 120 & 531 & 525 & 572 & 679 & 300 & 686 & 663 & 618 & 540 \\
\hline 140 & 636 & 663 & 700 & 787 & 320 & 553 & 525 & 471 & 370 \\
\hline 160 & 750 & 771 & 797 & 864 & - & - & - & - & - \\
\hline
\end{tabular}

Табличя 3

Основні статистики рядів прогнозу запасу для різновікових букових деревостанів із різною кількістю поколінь лісу та режимом лісовикористання

\begin{tabular}{ccccccccc}
\hline \multirow{2}{*}{$\begin{array}{c}\text { Позначення осно- } \\
\text { вних статистик }\end{array}$} & \multicolumn{2}{c}{$\begin{array}{c}\text { Для деревостанів без головного рубання } \\
\text { залежно від кількості поколінь лісу }\end{array}$} & \multicolumn{4}{c}{$\begin{array}{c}\text { Для деревостанів з головним рубанням } \\
\text { залежно від кількості поколінь лісу }\end{array}$} \\
\cline { 2 - 9 } & 5 & 4 & 3 & 2 & 5 & 4 & 3 & 2 \\
\hline$\overline{\mathrm{M}}, \mathrm{m}^{3} / \mathrm{ra}$ & 652 & 648 & 641 & 639 & 694 & 696 & 666 & 702 \\
$\sigma$ & 185 & 190 & 193 & 217 & 58 & 62 & 103 & 120 \\
$\mathrm{~V}_{\mathrm{M}} \%$ & 28,4 & 29,4 & 30,1 & 34,0 & 8,4 & 8,9 & 15,5 & 17,1 \\
$\mathrm{M}_{\mathrm{i}}-\overline{\mathrm{M}}(\mathrm{min}), \mathrm{m}^{3} / \mathrm{ra}$ & -248 & -247 & -253 & -269 & -112 & -112 & -193 & -194 \\
$\mathrm{M}_{\mathrm{i}}-\overline{\mathrm{M}}(\mathrm{max}), \mathrm{m}^{3} / \mathrm{ra}$ & 256 & 262 & 263 & 287 & 56 & 76 & 130 & 162 \\
\hline
\end{tabular}

Висновки. За результатами дослідження та їх аналітичного опрацювання отримано теоретичні динамічні ряди запасу різновікових букових деревостанів ${ }^{\mathrm{a}}$ класу бонітету в Українських Карпатах. Прогноз запасу деревостану диференційовано за поколіннями лісу.

За однакової кількості поколінь лісу в буковому деревостані із головним рубанням середній запас, обчислений для всього періоду прогнозу, більший, ніж в аналогічному об'єкті, але без рубання.
Прогноз і статистичний аналіз динамічних рядів запасу з економічного погляду дає змогу рекомендувати оптимальний варіант вікової структури. Під час формування доцільно віддавати перевагу різновіковим буковим деревостанам із 4-5-ти поколінь лісу. У межах окремої ділянки (таксаційного виділу) спостерігаються найменші коливання запасу деревини, а відтак в динаміці фактичний розподіл запасу буде найкраще відповідати концепції користування деревиною на принципах наближеного до природи лісівництва. 


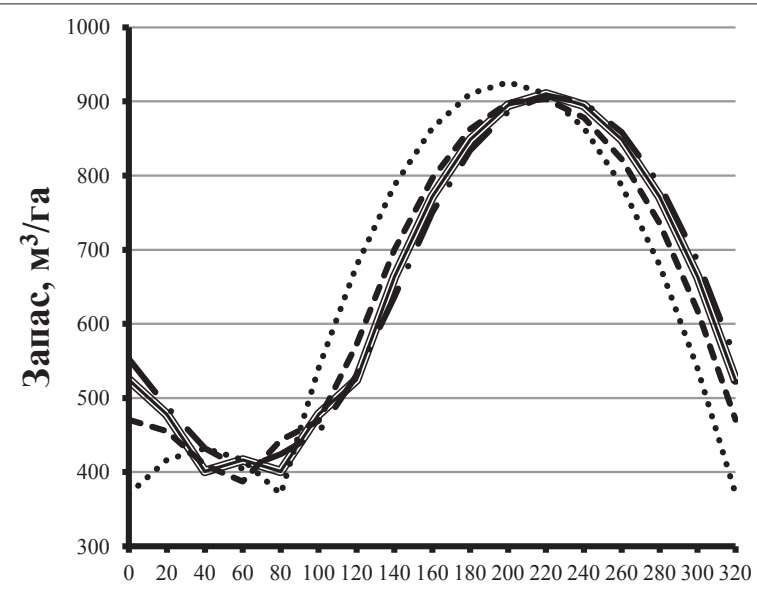

Період прогнозу, років

a)

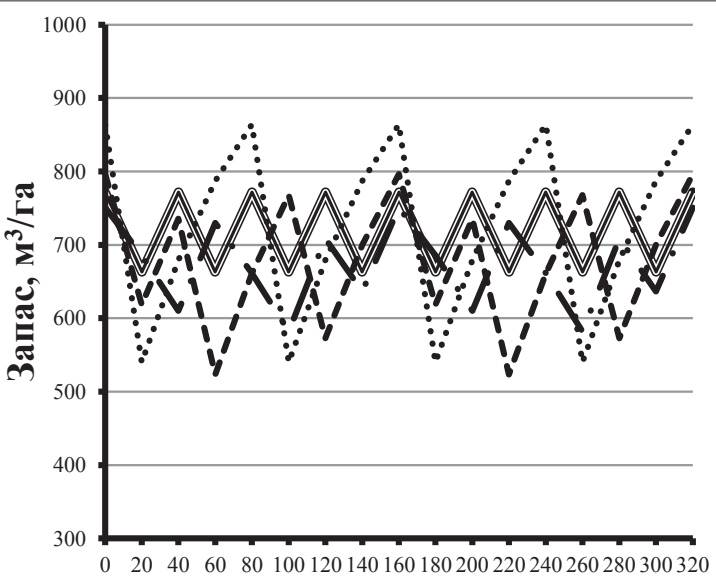

Період прогнозу, років

b)

Рис. 2. Особливості нагромадження запасу різновіковими буковими деревостанами I ${ }^{\mathrm{a}}$ бонітету в Українських Карпатах: а) без головного рубання; b) з головним рубанням

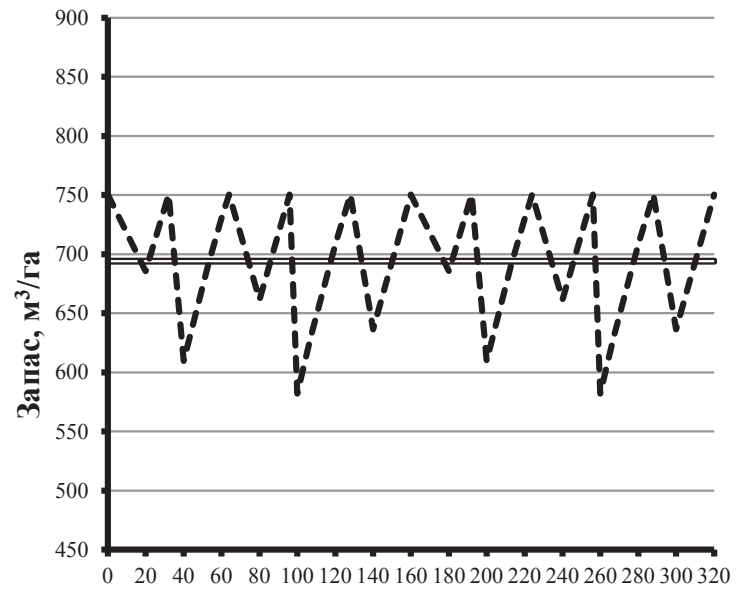

Період прогнозу, років

a)

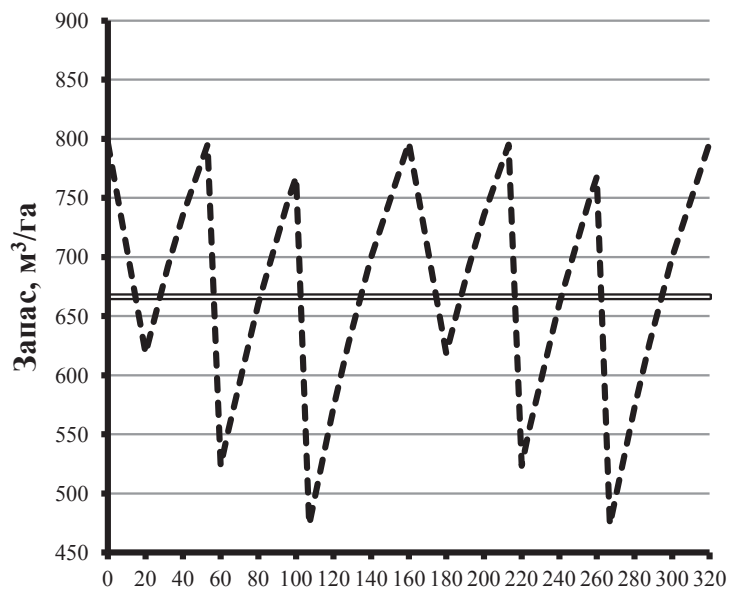

Період прогнозу, років

c)

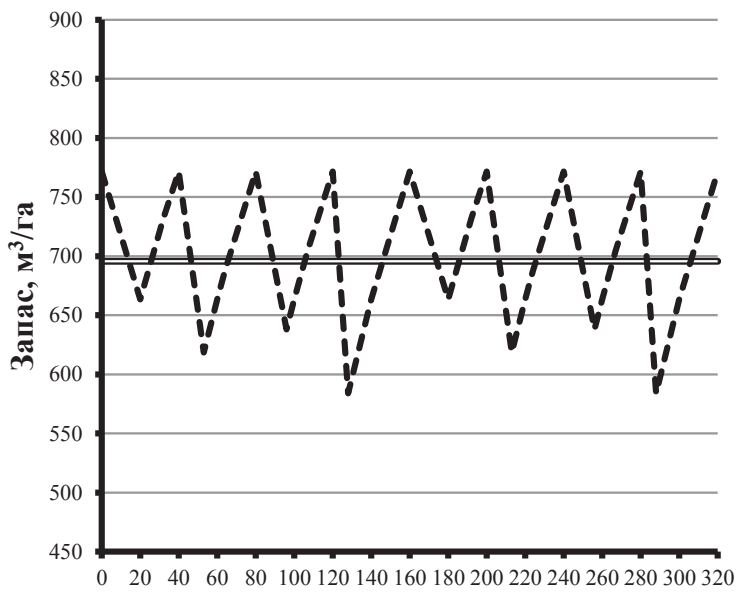

Період прогнозу, років

b)

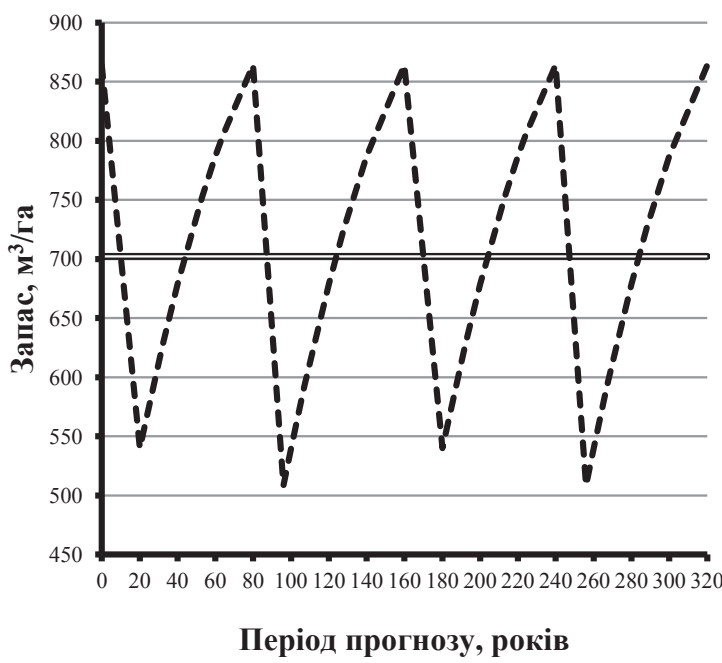

d)

Рис. 3. Коливання запасу в різновікових букових деревостанах I⿱ бонітету в Українських Карпатах (із головним рубанням): а) із п'яти поколінь лісу; b) із чотирьох поколінь лісу; с) із трьох поколінь лісу; d) із двох поколінь лісу 
В екологічному аспекті до бажаної моделі потрібно зарахувати варіант різновікового букового деревостану із 4-5-ти поколінь лісу без головного рубання. Середній запас, обчислений для всього періоду прогнозу у цих об'єктах, незначно відрізняється від деревостанів із 4-5-ти поколінь лісу з головним рубанням. Розмах варіації середнього запасу, обчисленого за весь період прогнозу, між деревостанами $з$ та без головного рубання перебуває в межах точності таксації цього показника.

\section{Бібліографічні посилання}

Anuchin, N. P. (1969). Forest inventory and unevenaged forest management. Moscow: Forest industry (in Russian).

Verkhunov, P. M. (1979). Growing stock increment in uneven-aged pine forests. Novosibirsk: Science, Siberian Branch (in Russian).

Voropanov, P.V. (1950). Spruce forests in the North. Moscow-Leningrad: Goslesbumizdat (in Russian).

Hirs, O.A., Novak, B. I., \& Kashpor, S. M. (2013). Forest management: Educational manual. Kyiv: Phytocenter (in Ukrainian).

Holubets, M.A. (2016). Fundamentals of restoring the functional nature of the Carpathian forests. Lviv: Company Manuscript (in Ukrainian).

Gusev, I. I. (1978). Productivity of spruce forests of the North. Leningrad: Publishing House of Leningrad University (in Russian).

Kahaniak, Yu. Y., \& Horoshko, M.P. (2016). Accumulation of growing stock by uneven-aged stands: insight into approaches and analysis of regularities. Scientific works of the Forestry Academy of Sciences of Ukraine, 14, 162-168 (in Ukrainian).

Kahaniak, Yu. Y., \& Rehuhs, N. V. (2014). Horizontal structure of beech stands of the Transcarpathian region. Scientific works of the Forestry Academy of Sciences of Ukraine, 12, 135-139 (in Ukrainian).

Kahaniak, Yu. Y. (2012). Productivity of uneven-aged beech stands on the north-eastern megaslope of the Carpathians. Forestry and park-and-garden management, 1, 64-70 (in Ukrainian). http://ejournal.studnubip.com

Kahaniak, Yu. Y. (2011). The structure of forest generations of uneven-aged beech stands on the north-eastern megaslope of the Carpathians. Scientific works of the Forestry Academy of Sciences of Ukraine, 9, 118120 (in Ukrainian).

Kahaniak, Yu. Y. (2006). Modeling the productivity of uneven-aged beech stands in the Carpathians. Scientific bulletin of the Ukrainian National Forestry University, 16.3, 8-14 (in Ukrainian).

Kuznetsova, V.G., \& Stoliarov, D.P. (1981). Development of uneven-aged spruce stands after selection felling. Leningrad: LenNIILKh (in Russian).

Krynytskyy, H.T., Chernyavsky, M.V., Derbal, Yu. Yu., Delehan, I. V., Myklush S. I., Parpan V.I., Shparyk, Y. S. (2014). Close-to-nature multifunctional forest management in the Carpathian region of Ukraine and Slovakia. Uzhgorod: Kolo (in Ukrainian).
Svalov, N.N. (1979). Modeling the productivity of stands and the theory of forest management. Moscow: Forest industry (in Russian).

Stoliarov, D.P. \& Poluboyarinov, O. I. (1989). Recommendations on estimation of structure, commodity composition, and quality of timber in uneven-aged spruce stands for the purpose of organization of a selection system: methodical recommendations. Leningrad: LenNIILKh (in Russian).

\section{Возрастная структура разновозрастных буковых древостоев Украинских Карпат и особенности накопления ими запаса}

\author{
Ю.И. Каганяк', М.П. Горошко²
}

Предмет научного труда составляет исследование возрастной структуры и динамики накопления запаса разновозрастными буковыми древостоями в Украинских Карпатах. Объектом исследования являются разновозрастные древостои, условно распределенные на две группы относительно главной рубки. Первая группа объединяет объекты, в которых реализирована главная рубка. Древостои второй группы характеризуют те категории защитности леса, в которых главная рубка запрещена. Моделированы разновозрастные буковые древостои с разным количеством поколений леса. Количество поколений леса колеблется от двух до пяти.

Предусмотрено оценить наличие связи между количеством возрастных поколений букового древостоя и величиной накопленного запаса. Оптимальный вариант возрастной структуры рекомендуется лесным предприятиям как эталон формирования объекта.

Прогноз накопленного запаса дифференцирован по поколениям леса и интегрирован в целом для древостоя. Период прогноза принято в пределах от 0 до 320 лет. Средний возраст первого поколения леса текущего цикла совпадает с величиной периода прогноза запаса. Средний возраст остальных поколений леса смещён относительно периода прогноза запаса. Этот показатель вычислен по предложенному в научном труде алгоритму. Запас поколения леса моделируется параболой второго порядка, аргументом которой принято возраст.

Каганяк Юлиан Иосифович - член-кореспондент Лесной академии наук Украины, доктор сельскохозяйственных наук, профессор кафедры лесной таксации и лесоустройства. Национальный лесотехнический университет Украины, ул. генерала Чупринки, 103, г. Львов, 79057, Украина. Тел.: +38-067-587-4266. E-mail: kaganiak@yahoo.ca

Горошко Мирон Петрович - член-кореспондент Лесной академии наук Украины, кандидат сельскохозяйственных наук, профессор, заведующий кафедры лесной таксации и лесоустройства. Национальный лесотехнический университет Украины, ул. генерала Чупринки, 103, г. Львов, 79057, Украина. Тел.: +38-097-500-90-09. E-mail: mag_lanu@ukr.net 
Сравнение среднего запаса объектов в обеих группах, но с равным количеством поколений леса, позволяет сформулировать следующую тенденцию. В буковых древостоях с главной рубкой, средний запас, вычисленный для целого периода прогноза, больше, чем в объектах без рубки.

Амплитуда запаса меньше приблизительно в 2-3 раза в древостоях с главной рубкой. Амплитуда запаса растёт прямо пропорционально увеличению количества поколений леса. В древостоях без главной рубки уменьшение количества поколений леса менее выразительно отображается на увеличении колебания запаса. В древостоях из 4-5-ти поколений леса с главной рубкой амплитуда запаса в 2 раза меньше, чем в древостоях из 3-2-х поколений.

Прогноз и статистический анализ динамических рядов запаса позволяет рекомендовать оптимальный вариант возрастной структуры с условием обеспечения стабильных лесозаготовок. При формировании целесообразно отдавать предпочтение разновозрастным буковым древостоям из 4-5-и поколений леса. Для отдельного участка наблюдается в этом случае наименьшее колебание запаса древесины. Это значит, что в динамике фактическое распределение запаса будет наилучше соответствовать концепции использования древесины на принципах приближённого к природе лесоводства.

Учитывая амплитуду запаса и иные статистические исчисления, в качестве оптимальной модели принято разновозрастной буковый древостой, который состоит из 4-5-ти поколений леса.

Ключевые слова: теория, модель, динамика, выборочное хозяйство, возрастное поколение леса, форма хозяйства, амплитуда

\section{Age structure of uneven-aged beech stands in the Ukrainian Carpathians and peculiarities of growing stock accumulation}

\author{
Yu. Kahaniak' ${ }^{1}$ M. Goroshko²
}

Abstract. The subject of the scientific work is the study of the age structure and dynamics of growing stock accumulation in uneven-aged beech stands in the Ukrainian Carpathians. The object of the study is

Yulian Kahaniak-Corresponding Member of the Forestry Academy of Sciences of Ukraine, Doctor of Agricultural Sciences, Professor of the Department of Wood Taxation and Forest Management Ukrainian National Forestry Universiti. General Chuprynka st., 103, lviv, 79057, Ukraine. Tel.: +38-067-587-42-66. E-mail: kaganiak@yahoo.ca

Myron Horoshko - Corresponding Member of the Forestry Academy of Sciences of Ukraine, PhD of Agricultural Sciences, Professor, Head of the Department of Wood Taxation and Forest Management. Ukrainian National Forestry Universiti. General Chuprynka st., 103, lviv, 79057, Ukraine. Tel.: +38-097-500-9009. E-mail:mag_lanu@ukr.net uneven-aged forest stands, arbitrarily divided into two groups in relation to main felling. The first group comprises the sites in which the main felling was conducted. The stands of the second group characterize those categories of forest protectiveness in which the main felling is prohibited. Uneven-aged beech stands with different generations of forest are modeled. The number of generations in the forest ranges from two to five.

It is envisaged to assess the relationship between the number of age-generations of beech forest stand and the amount of accumulated growing stock. The optimal version of age structure is recommended for forest enterprises as a standard for object formation.

The forecast of accumulated growing stock is differentiated according to forest generations and is integrated as a whole for the stand. The forecast period is in the range from 0 to 320 years. The average age of the first generation of the current cycle coincides with the value for the forest stock forecast period. The average age of the remaining generations of the forest is displaced with respect to the period of the growing stock forecast. This figure is calculated by the algorithm proposed in the scientific paper. The growing stock of forest generation is modeled by a second-order parabola, the argument of which is age.

A comparison of the average growing stock volume of objects in both groups, but with an equal number of generations of the forest, allows us to formulate the following trend. In beech stands with the main felling conducted, the average growing stock calculated for the whole forecast period is greater than in the areas without cutting.

The amplitude of the growing stock is approximately 2-3 times less in stands with final felling. The growing stock amplitude increases in direct proportion to the increase in the number of generations of the forest. In stands without main felling, a decrease in the number of forest generations is less expressively displayed on an increase in the stock fluctuation. In stands of 4-5 generations of forest with main felling, the growing stock amplitude is 2 times less than in stands of 3-2 generations.

The forecast and statistical analysis of the dynamic series of the growing stock allows us to recommend the optimal variant of the age structure with the condition of ensuring stable logging. When forming the stand, it is recommended to give preference to uneven-aged beech stands of 4-5 generations of forest. In this case, the smallest fluctuation of the timber stock is observed for an individual site. This means that, in the dynamics, the actual distribution of the growing stock will be best suited to the concept of the forest management on the principles of the close-to-nature forestry.

Considering the amplitude of the growing stock and other statistical calculations, an uneven-aged beech forest stand, which consists of 4-5 generations of forest, is taken as the optimal model.

Key words: theory, model, dynamics, selection system, age generation of the forest, silvicultural type, amplitude 